Jurnal Ilmu-Ilmu Peternakan 26 (3): 59 - 78

ISSN : 0852-3681

E-ISSN : 2443-0765

CFakultas Peternakan UB, http://jiip.ub.ac.id/

\title{
Fitat dan fitase : dampak pada hewan ternak
}

\author{
Yanuartono, Alfarisa Nururrozi dan Soedarmanto Indarjulianto \\ Fakultas Kedokteran Hewan Universitas Gadjah Mada \\ Jl. Fauna No.2, Karangmalang, Depok, Sleman. 55281 Yogyakarta
}

yanuartono20@yahoo.com

\begin{abstract}
In countries with high plant biodiversity such as Indonesia, the availability of food of plant origin is very diverse. The presence of anti-nutrients in plants would potentially cause problems in cattle if not managed properly. phytic acid is one anti nutritional factor that have a role in disrupting the health and productivity The term phytate refers to the molecule phytic acid, which generally acts as a chelate to $\mathrm{Mg}$, $\mathrm{Ca}, \mathrm{Na}$, and $\mathrm{K}$, and in some cases protein and carbohydrates. Seeds of cereals, legumes and oilseed plant which is used as animal feed usually contains a lot of phytic acid which can cause a decline in nutritional value. However, with a variety of processing methods, levels of phytic acid in animal feed can be reduced or even eliminated. In addition to the processing method, the method of adding phytase enzyme may also be done to improve the nutritional value of the animal feed ingredients.
\end{abstract}

Keywords:anti-nutrients.phytic acid. processingmethods.phytase

PENDAHULUAN

Pakan ternak memiliki kandungan nutrisi, vitamin dan mineral yang berguna bagi pertumbuhan dan kesehatan. Namun demikian pakan ternak dapat mengandung racun alami yang disebut sebagai faktor antinutrisi. Faktor antinutrisi tersebut memiliki potensi membahayakan kesehatan ternak yang mengkonsumsinya. Faktor antinutrisi adalah zat yang baik secara langsung atau melalui produk metabolisme mereka, mengganggu pemanfaatan pakan dan mempengaruhi kesehatan serta produksi hewan melalui mekanisme penurunan asupan nutrisi, gangguan pencernaan dan penyerapan serta mengakibatkan efek samping merugikan lainnya (Akande et al., 2010).

$\begin{array}{lrr} & \text { Salah satu faktor antinutrisi } \\ \text { yang } & \text { memiliki peran } & \text { dalam } \\ \text { mengganggu produktivitas } & \text { ternak }\end{array}$

adalah asam fitat. Istilah fitat mengacu untuk molekul asam fitat, yang umumnya berperan sebagai chelate untuk Magnesium $(\mathrm{Mg})$, kalsium $(\mathrm{Ca})$, Natrium (Na), besi $(\mathrm{Fe})$, seng ( $\mathrm{Zn})$ dan Kalium (K), serta dalam beberapa kasus protein dan karbohidrat (Selle et al., 2000). Kandungan asam fitat dalam bahan pakan dapat diturunkan atau bahkan dihilangkan melalui berbagai macam metode pengolahan. Proses pengolahan tersebut antara lain adalah perendaman, perkecambahan, perebusan, pemasakan dan fermentasi. Selain metode pengolahan bahan pakan, peningkatan nilai nutrisi pakan juga dapat dilakukan dengan penambahan fitase yang berasal dari 
mikroorganisme. Dalam beberapa tahun terakhir, penambahan fitase asal mikroorganisme(Aspergillus niger, Peniophoralycii, Escherichia coli) ke dalam pakan ternak semakin banyak dilakukan karena kemampuannya menghidrolisa asam fitat yang terkandung pada bahan pakan menjadi senyawa inositol dan glukosa serta senyawa fosfor organik sehingga meningkatkan kecernaan fosfor dan penyerapan mikro mineral lainnya (Ravindran et al., 2000). Penambahan fitase merupakan salah satu cara untuk mengatasi tingginya asam fitat dalam ransum.

\section{Struktur dan sifat asam fitat}

Nama kimia untuk asam fitat adalah myo-inositol 1,2,3,4,5,6-hexakis phosphate dengan formula $\mathrm{C}_{6} \mathrm{H}_{18} \mathrm{O}_{24} \mathrm{P}_{6}$. Asam fitat memiliki fosfor bermuatan negatif yang besar sehingga asam fitat mampu berikatan dengan banyak kation divalen, protein, dan karbohidrat.Garam dari asam fitat disebut sebagai phytates (Grafs et al., 1987; Kerovuo et al., 2000).Fosfatyang berikatan pada asam fitat terdiri dari dua posisi yaitu aksial dan ekuatorial, terdapat lima gugus Pberada dalam posisi equator dan satu gugus dengan posisi aksial (Bohn et al., 2008).

Asam fitat memiliki struktur kimia yang sangat stabil dan jika berada dalam bentuk $\mathrm{P}$ organik memilki kandungan fosfat yang tinggi. Dalam kondisi fisiologi normal asam fitat membentuk chelate dengan mineral mineral essensial seperti $\mathrm{Ca}, \mathrm{Mg}, \mathrm{Fe}$ dan $\mathrm{Zn}$. Asam fitat seringkali berikatan dengan asam-asam amino atau menghambat enzim-enzim pencernaan (Pallauf and Rimback, 1996). Fosfat dengan muatan negatif yang terdapat pada asam fitat dapat dengan kuat mengikat logam kation seperti $\mathrm{Ca}, \mathrm{Fe}, \mathrm{K}, \mathrm{Mg}, \mathrm{Mn}$, dan $\mathrm{Zn}$ sehingga menjadi tidak larut dan me- nyebabkan logam kation tersebut tidak tersedia sebagai faktor nutrisi (Bohn et al., 2008; Weaver and Kannan, 2002).

Singh et al. (1991) menyatakan bahwa ada korelasi negatif yang nyata antara fitat dan daya cerna protein in vitro pada kacang tanah. Tampaknya fitat menurunkan daya cerna protein dengan mengganggu aktivitas enzim protease. Hasil penelitian tersebut menunjukkan bahwa asam fitat kemungkinan menghambat aktivitas enzim.Conrad et al. (1996), menyatakan bahwa asam fitat menghambat aktivitas enzim tripsin. Metabolisme ini melibatkan chelate mineral dan menghilangkan kofaktor serta membutuhkan aktivitas enzim secara optimal akibat terbentuknya reaksi kompleks fitat-enzim. Kemampuan asam fitat yang lain adalah dapat menghambat aktivitas amilase baik secara langsung atau tidak langsung dengan chelating $\mathrm{Ca}$, yang merupakan kofaktor yang diperlukan untuk amilase (Rickard and Thompson, 1997).

Selama ini telah diketahui bahwa beberapa protein dari sereal dan legum membentuk ikatan antara fitat dengan protein yang dapat mempengaruhi daya cerna protein. Bentuk ikatan tersebut diyakini diyakini akan menghambat degradasi enzimatik dari protein. Hasil hasil penelitian menunjukkan bahwa asam fitat mampu menekan pemanfaatan protein dan atau asam amino, dengan membentuk kompleks fitat-protein sehingga menyebabkan perubahan pada struktur protein. Perubahan struktur tersebut akan mengakibatkan penurunan kelarutan protein, aktivitas enzim dan kecernaan protein (Deshpande and Damodaran, 1989; Urbano et al., 2000; Greiner and Konietzny, 2011).

Menurut Baldwin (2001) fitat dapat berinteraksi dengan karbohidrat baik secara langsung atau tidak lang- 
sung dengan melalui interaksi Starch Granuleassociated Proteins(SGAP). Interaksi secara langsung dengan cara mengikat amilum melalui ikatan hidrogen, atau secara tidak langsung melalui protein yang terkait dengan amilum. Interaksi antara fitat dengan karbohidrat tersebut berpengaruh terhadap daya cerna dan penyerapan glukosa (Rickard dan Thompson, 1997).

\section{Sumber asam fitat}

Biji tanaman sereal, legum, dan oilseed plant banyak digunakan sebagai sumber nutrisi yang penting bagi hewan.Selain sebagai sumber karbohidrat, protein dan lemak, biji-bijian tersebut juga bertindak sebagai sumber mineral yang penting bagi pertumbuhan seperti $\mathrm{P}$, $\mathrm{Ca}$, Fe, dan $\mathrm{Zn}$ (Morris, 1986).Namun demikian biji-bijian tersebut banyak mengandung asam fitat yang menyebabkan nilai nutrisinya menjadi rendah.Steiner et al. (2007) melaporkan bahwa sekitar $67 \%$ dari total P dalam biji legum, sereal, oilseed plant dan limbah sereal berikatan dengan asam fitat.Pada bijian sereal, asam fitat banyak terdapat pada lapisan terluar biji, sementara di sebagian besar oilseeds dan bijian legum asam fitat terutama terletak di lapisan aleuron dan dedak luar (Angel et al., 2002; Steiner et al., 2007). Tanaman sereal, legum, dan oilseed tersebut antara lain kedelai (Glycine max L) (Raboy and Dickinson, 1993), kacang tanah (Arachis Hypogaea) (Panhwar, 2005), barley (Hordeum vulgare), gandum (Triticum aestivum), buncis (Phaseolus vulgaris) (Reddy et al., 1982), Phaseolus lunatus (Ologhobo et al., 1982), padi (Oryza sativa), biji jagung (Zea mays) (O’Dell et al., 1972). Kandungan asam fitat dalam tanaman maupun bijian tersebut dipengaruhi oleh genetika, kondisi iklim, kondisi lokasi, irigasi, jenis tanah, tahun dan pemupukan (Reddy et al., 1989). Sebagai negara yang kaya akan keragaman hayati, Indonesia memiliki banyak ragam tanaman legum dan sereal. Tanaman legum seperti gamal (Gliricidia), turi (Sesbania grandiflora), petai cina (Leucaena leucocephala), kaliandra (Calliandra calothyrsus), puero (Pueraria phaseoloides), orok orok (Crotalaria juncea), lamtoro mini (Desmanthus virgatus), stilo (Stylosanthes graciliaris), siratro (Macroptilium atropurpureum), kembang telang (Clitoria ternatea L.) dan Indigofera Sp. Sedangkan jenis sereal adalah padi (Oryza sativa L.) jagung (Zea mays L.) sorghum (Sorghum bicolor L.) kedelai (Glycine max L.) dan juwawut (Setaria italica (Linn.) P. Beauv.)

Di Indonesia, hanya beberapa sumber pakan ternak asal bijian yang telah digunakan. Hal tersebut karena kemungkinan berkaitan dengan harga, jumlah volume panen dan pemanfaatan lebih ke konsumsi untuk manusia.Di Indonesia sumber pakan ternak asal bijian yang telah digunakan yang murah dan mudah didapat adalah dedak padi bungkil kedelai dan jagung.Dedak padi adalah hasil limbah penggilingan padi yang digunakan sebagai pakan ternak, baik monogastrik maupun ruminansia.Namun demikian, meskipun murah dan mudah didapat, sumber pakan tersebut banyak mengandung asam fitat. Asam fitat dalam padi terutama terdapat dalam lembaga (germ) dengan kandungan sebesar 7,6 g $100 \mathrm{~g}^{1}$ dan endosperma sebesar 1,2 g $100 \mathrm{~g}^{1}$ (O'Dell et al., 1972). Sedangkan konsentrasi asam fitat dalam dedak padi yang terdiri dari pericarp, aleuron dan lembaga, adalah sebesar 5,94-6,09 g $100 \mathrm{~g}^{1}$ (Kasim and Edwards, 1998). Oleh karena dedak padi mengandung asam fitat yang cukup tinggi maka diperlukan metode untuk meningkatkan nilai nutrisi bahan tersebut. 
Hasil penelitian Lolaset al. (1976) menunjukkkan bahwa konsentrasi asam fitat dalam kedelai memiliki sedikit variasi. Dari 15 varietas kedelai yang diteliti, kandungan asam fitat berkisar antara $1 \%$ sampai $1,47 \%$ dari berat kering, dengan nilai rata rata $1,14 \%$. Sedangkan hasil penelitian Harland and Prosky (1979) menunjukkan konsentrasi asam fitat dalam kedelai yang lebih tinggi yaitu $2,22 \%$. Hasil penelitian lebih rinci oleh Greiner dan Konietzny (2006) menunjukkan bahwa kandungan asam fitat dalam biji kedelai dapat mencapai 9,2-16,7 mg/g butir.

Sekitar 50-80\% P dalam bungkil kedelai terikat dalam kompleks asam fitat sehingga dapat menyebabkan masalah pencemaran lingkungan dan meningkatnya biaya pemeliharaan ternak unggas dan babi (Eeckhout dan De Paepe, 1994; Tyagi and Verma, 1998; Knowlton et al., 2004). Hasil penelitian Glencross (2004) menunjukkan bahwa sejumlah19.9mg/kg P pada bungkil kedelai terdapat dalam bentuk kompleks asam fitat. Fermentasi bungkil kedelai dengan bakteri penghasil fitase dapat dilakukan sebagai salah satu usaha untuk menurunkan kadar asam fitat pada bungkil kedelai.

Selain dedak padi dan bungkil kedelai, bahan pakan yang paling banyak digunakan sebagai sumber energi monogasrik pada ayam adalah jagung. Dalam ransum unggas, baik ayam broiler maupun petelur, jagung menyumbang lebih dari separuh energi yang dibutuhkan ayam. Tingginya kandungan energi jagung berkaitan dengan tingginya kandungan karbohidrat $(>60 \%)$ biji jagung. Di samping itu, jagung mempunyai kandungan serat kasar yang relatif rendah sehingga cocok untuk pakan ayam. Berbeda dengan bijian sereal, kandungan fitat pada jagung $80 \%$ terdapat dalam lembaga (germ).
Kandungan asam fitat pada jagung sebesar $0,75-2,22 \%$ dari berat kering atau $367 \mathrm{mg} / 100 \mathrm{~g}$ (Sokrab et al., 2011).Namun demikian, kandungan fitase dalam jagung cukup rendah sehingga dalam proses pengolahan yang seerhana akan hilang. Kandungan asam fitat dalam jagung tersebut menyebabkan penggunaannya sebagai pakan unggas perlu dibatasi (Anggorodi, 1995). Berbagai metode telah dikembangkan untuk menurunkan kadar fitat dalam bahan makanan dan pakan, antara lain rekayasa genetika, germinasi, perendaman, perlakuan dengan fitase serta fermentasi (Gupta, 2013).

Banyaknya ragam bijian sereal, legum di Indonesia menjadikan kita harus meneliti lebih lanjut sumber sumber pakan asal sereal, legum tersebut yang dapat dimanfaatkan sebagai sumber pakan ternak. Penelitian tersebut sebaiknya dilanjutkan dengan usaha budidaya sehingga dapat memenuhi kebutuhan bahan pakan ternak.

\section{Pengaruh fitat pada ruminansia}

Ruminansia memiliki mikroba dalam rumen yang dapat menghasilkan fitase. Enzim tersebut mampu memecah ikatan $P$ dengan fitat sehingga $P$ dapat terabsorbsi. Beberapa hasil penelitian menunjukkan bahwa fitat hanya sedikit atau bahkan sama sekali tidak ada di feses ruminansia yang mengkonsumsi konsentrat (Morse et al., 1992). Dari hasil penelitian tersebut dapat disimpulkan bahwa mikroorganisme rumen mampu menghidrolisis seluruh fitat dalam rumen. Selain itu menurut Van Soest (1994) tidak ada efek negatif dari fitat terhadap penyerapan mineral di ruminansia. Namun demikian, menurut Jarrett et al. (2014) pada sapi perah yang berproduksi tinggi, pakan akan cepat melintasi rumen sehingga 
kemungkinan degradasi fitat melalui fermentasi akan menjadi terbatas. Hal tersebut disebabkan karena singkatnya waktu fitat terpapar oleh fitase mikroba. Menurut Morse et al. (1992), degradasi fitat akan lambat dan hanya sebagian dari $P$ yang dimanfaatkan ketika senyawa tersebut berubah konfigurasinya dengan membentuk kompleks dengan $\mathrm{Ca}$. Namun apabila terbentuk kompleks dengan $\mathrm{Zn}$ menjadi kompleks Zn-fitat, kompleks tersebut kemungkinan akan didegradasi dan melepaskan $\mathrm{Zn}$ secara perlahan-lahan yang akan dimanfaatkan untuk pertumbuhan mikroba rumen dan memacu pertumbuhan ternak(Hernaman dkk. 2007). Penelitian oleh Park et al. (2002) menunjukkan bahwa domba mampu mendegradasi sebagian asam fitat bungkil biji kapas di dalam usus besar, meskipun demikian lebih dari $10 \% \mathrm{P}$ dalam pakan dalam bentuk inositol fosfat diekskresikan dalam feses. Hal ini menunjukkan bahwa bungkil biji kapas mengandung $\mathrm{P}$ yang tidak tersedia untuk domba dan degradasi fitat terutama terjadi didalam rumen.

Pada ruminansia, pemberian bijian sereal, legum, dedak padi, bungkil kedelai tampaknya sampai saat ini tidak menimbulkan masalah karena mikroba dalam rumen yang dapat menghasilkan fitase. Apalagi bahan pakan tersebut tidak pernah menjadi pakan utama untuk ternak ruminansia. Bahan pakan tersebut biasanya disebut konsentrat dan diberikan hanya sekitar 1-3\% dari bobot badan.

\section{Pengaruh fitat pada monogastrik}

Pembentukan kompleks mineral fitat yang tidak larut dapat menghambat penyerapan mineral pada saluran pencernaan, hal ini akan mengurangi ketersediaan mineral penting bagi tubuh (Kerovou et al., 2000). pH merupakan fak- tor penting yang mempengaruhi kelarutan fitat. Fitat lebih mudah larut di $\mathrm{pH}$ rendah $(<2)$ dibandingkan dengan $\mathrm{pH}$ tinggi (4-7) (Selle et al., 2000). Oleh karena itu, fitat secara nyata mempengaruhi kecernaan $\mathrm{Ca}$ dan $\mathrm{P}$. Pada $\mathrm{pH} 1$ sampai 6, kisaran normal $\mathrm{pH}$ di dalam lambung babi asam fitat dapat membentuk kompleks dengan kation divalen seperti $\mathrm{K}, \mathrm{Ca}, \mathrm{Mg}$, dan $\mathrm{Zn}$ (BebotBrigand et al., 1999). Pada kisaran $\mathrm{pH}$ tersebut, asam fitat juga dapat membentuk kompleks dengan protein baik langsung melalui interaksi fitat-protein pada $\mathrm{pH}$ rendah atau melalui interaksi tiga serangkai ion-protein fitat-divalen pada pH tinggi (Cheryan, 1980).Dengan demikian, kompleks antara asam fitat dan mineral akan larut di bawah kondisi asam dalam lambung. Peningkatanan $\mathrm{pH}$ akan terjadi seiring dengan perjalanan dari lambung ke usus kecil sehingga akan menyebabkan penurunan absorbsi mineral. (Schlemmer et al., 2009; Selle et al, 2009).Asam fitat dapat tercerna apabila terdapat fitase dalam saluran pencernaaan ternak.Ternak nonruminansia seperti babi dan ayam tidak memiliki fitase sehingga tidak mampu mendegradasi fitat menjadi fosfor tercerna (Greiner and Konietzny, 2011). Fosfor merupakan elemen penting bagi kehidupan untuk hewan, Akan tetapi karena sebagian besar disimpan dalam bentuk garam fitat dalam biji tanaman, maka ketersediaannya untuk hewan monogastrik seperti babi dan unggas menjadi berkurang (Reddy et al., 1982; Selle et al., 2009; Humer et al., 2015). Ketersediaan $\mathrm{P}$ juga akan berkurang di hewan monogastrik karena mereka tidak memiliki fitase yang dibutuhkan untuk melepas $\mathrm{P}$ sehingga dapat diserap, dengan demikian sebagian besar $\mathrm{P}$ akan diekskresikan. Penambahan fosfor anorganik seperti dikalsium fosfat atau monokalsium monofosfat dalam ransum ternak non ruminansia diperlukan untuk 
memenuhi kebutuhan fosfor (Soares Jr. 1995).

Hasil penelitian Piliang et al.(1982) menunjukkan bahwa pada ayam petelur dengan pemberian dedak padi sebanyak $81,5 \%$ dalam ransum mengakibatkan produksi telur lebih rendah dibandingkan dengan ayam yang diberikan dedak sebanyak $39 \%$ atau $19,5 \%$ dalam ransum. Rendahnya produksi telur tersebut kemungkinan karena dedak padi mengandung asam fitat dan serat kasar yang cukup tinggi. Aktivitas fitase pada brush border usus yang tertinggi pada duodenum kemudian terjadi penurunan secara progresif di sepanjang usus halus. Aktivitas total fitase pada brush border usus paling tinggi adalah $35 \%$, yaitu pada usus halus ayam petelur. Fitase pada brush border usus memberikan kontribusi pada pencernaan fitat-P dan berperan dalam pengaturan sebagai respons terhadap kebutuhan $\mathrm{P}$ dan vitamin D dari ayam (Maenz and Classen, 1998).

Penggunaan dedak padi sebagai bahan pakan babi cukup tinggi yaitu mencapai $30-40 \%$ di dalam ransum. Hal ini disebabkan karena beberapa faktor antara lain, produksinya yang relatif banyak, tidak dimanfaatkan sebagai bahan makanan manusia, harga relatif rendah serta kandungan nutriennya relatif baik sebagai pakan ternak. Disamping kelebihan tersebut diatas, dedak padi memiliki kelemahan yang salah satunya adalah mengandung asam fitat yang dapat mengikat mineral sehingga penyerapan mineral akan terganggu. Kandungan asam fitat dalam diet untuk babi secara umum telah terbukti menurunkan penampilannya (Woyengo and Nyachoti, 2013). Kandungan fitat dalam pakan babi biasanya antara 7 dan $10 \mathrm{~g} / \mathrm{kg}$ dari diet (Selle et al., 2009; National Research Council, 2012). Hasil penelitian
Woyengo et al. (2009) menunjukkan adanya penurunan absorbsi natrium dan magnesium dalam ileum anak babi yang diberi diet mengandung asam fitat cukup tinggi. Namun demikian penelitian pada babi yang diberikan diet rapeseed dengan kandungan $\mathrm{Ca}$ yang tinggi mengakibatkan degradasi fitat dalam saluran pencernaan sebesar $72 \%$. Selanjutnya penelitian itu juga menunjukkan bahwa suplementasi diet kalsium karbonat mengurangi degradasi fitat dalam usus babi, tapi tidak dalam lambung dan usus kecil (Sandberg et al.,1993).

\section{METODE PENURUNAN KAN- DUNGAN ASAM FITAT}

Berbagai teknik pemrosesan dan pengolahan pakan, bersama dengan penambahan enzim eksogen adalah usaha yang telah dilakukan dan bertujuan untuk menurunkan jumlah fitat dalam pakan ternak (Kumar et al., 2010). Metode pemrosesan secara fisik seperti perendaman, perkecambahan perebusan, pemasakan dan fermentasi merupakan metode yang umum dipakai untuk pemrosesan biji tanaman sereal, legum, dan oilseed plant. Metode metode tersebut biasanya akan menurunkan kandungan asam fitat dan meningkatkan kelarutan unsur hara (Selle and Ravindran 2008; Bilyeu et al., 2008).

Menurut Kumar et al. (2010) metode perendaman dalam waktu paling sedikit semalam, secara umum memang akan menurunkan kandungan asam fitat dalam bijian. Namun demikian, metode perendaman juga akan menurunkan unsur unsur nutrisi yang lain. Hasil penelitian Abdel-Gawad, (1993) menunjukkan perendaman bijian legum dengan air atau natrium bikarbonat akan mengakibatkan penurunan konsentrasi sukrosa. Hal tersebut tidaklah mengherankan karena sifat dari fitat yang larut dalam air. 
Metode perendaman tunggal dari beberapa penelitian hasilnya cukup menarik karena menunjukkan hasil saling bertentangan. Hasil penelitian Akindahunsi (2004) menunjukkan adanya peningkatan kandungan fitat setelah perendaman kacang minyak Afrika (African oil beans). Hasil yang sama juga diperoleh pada perendaman kacang kedelai selama 12 - 14 jam akan meningkatkan kandungan fitat sebesar 1,71\% (Egounlety and Arowh. 2003). Akan tetapi hasil peneltian oleh Mahmod et al. (2007) menunjukkan hasil yang sebaliknya.Perendaman kacang hijau dan kacang merah menunjukkan penurunan kandungan fitat. Terjadi penurunan fitat dalam kacang hijau sebesar $12,3 \%$ pada perendaman selama 12 jam, sedangkan pada kacang merah terjadi penurunan sebesar $15,6 \%$. Namun penelitian oleh Vidal-Valverde et al. (1998) menunjukkan hasil berbeda, dimana tidak terjadi perubahan yang nyata kandungan asam fitat pada perendaman kacang faba. Mengingat bahwa asam fitat bersifat stabil, akan dibutuhkan waktu yang cukup lama untuk perendamannya. Proses perendaman merupakan proses awal dalam usaha menurunkan bermacam macam kandungan antinutrisi termasuk di dalamnya adalah asam fitat. Proses tersebut selanjutnya diikuti oleh perebusan dan pemasakan.

Perkecambahan merupakan metode penurunan asam fitat secara sederhana dengan biaya yang murah serta telah lama dikerjakan oleh penduduk di Inonesia.Perkecambahan sendiri adalah proses alami yang terjadi selama masa pertumbuhan benih di mana mereka memenuhi kondisi minimum untuk pertumbuhan dan perkembangan (Sangronis et al., 2006). Selama proses perkecambahan, terjadi aktivasi enzim dan peningkatan ketersediaan serta kecernaan nutrisi. Disisi lain, faktor faktor antinutrisi mengalami penurunan kan- dungan (Osman, 2007). Metode perkecambahan dengan cepat akan menurunkan konsentrasi asam fitat disertai dengan peningkatan aktivitas fitase (Laboure et al., 1993). Menurut Shimelis and Rakshit (2007), kandungan asam fitat pada kacang ginjal akan menurun lebih dari $75 \%$ setelah 4 hari berkecambahan. Selain memiliki kemampuan menurunkan kandungan asam fitat, metode perkecambahan juga memiliki sisi positif yang lain. Menurut El-Adawy et al. (2002), perkecambahan juga adalah dilaporkan terkait dengan peningkatan vitamin konsentrasi dan bioavailabilitas elemen dan mineral. Hasil penelitian juga menemukan bahwa perkecambahan meningkat kalsium, tembaga, mangan, seng, riboflavin, niasin, dan kadar asam askorbat Kaushik et al. (2010).

Asam fitat adalah senyawa yang sangat stabil sehingga sulit terdegradasi dengan perebusan sesaat. Namun sebaliknya, fitase dalam bijian bersifat tidak stabil terhadap panas sehingga proses perebusan akan membuat enzim tersebut menjadi tidak aktif. Penurunan kandungan fitat selama proses perebusan kemungkinan disebabkan oleh terlarutnya fitat ke dalam air sebagai media perebusan. Kemungkinan lain adalah terjadinya degradasi dari kompleks fitat-protein dan atau fitatmineral oleh panas pada proses perebusan (Siddhuraju and Becker, 2001). Proses perebusan tersebut juga akan mengakibatkankerusakan komponen nutrisi yang lain seperti protein dan vitamin. Semakin lama waktu perebusan akan semakin menurunkan kandungan fitat, akan tetapi kandungan nilai nutrisi yang lain juga akan menurun atau bahkan hilang. Oleh sebab itu, untuk proses perebusan hanya dianjurkan untuk varietas bijian bijian yang memiliki kandungan fitase yang stabil terhadap panas atau dengan penambahan fitase dari luar yang 
bersifat stabil terhadap panas (Kumar et al., 2010).

Metode fermentasi adalah metode tradisional yang telah lama sekali digunakan karena teknologinya cukup sederhana, biaya yang murah dan mampu meningkatkan nilai nutrisi cukup besar. Perubahan tersebut meliputi tekstur, karakteristik organuleptik seperti rasa, aroma, penampilan, konsistensi, peningkatan kualitas dan eliminasi antinutrisi sebagian atau seluruhnya (Reinhold, 1975). Fermentasi bijian merupakan metode yang paling efektif untuk meningkatkan kecernaan protein dan karbohidrat serta ketersediaan mineral serta menurunkan tingkat anti-nutrisi seperti asam fitat dan polifenol (Dhankher dan Chauhan, 1987; Mahajan and Chauhan, 1987). Selain bijian, fermentasi juga dilakukan pada limbah bijian seperti bungkil kedelai. Lim et al. (2010) menyatakan bahwa fermentasi bungkil kedelai akan menghilangkan atau menginaktivasi faktor antinutrisi. Fermentasi tersebut juga akan meningkatkan nilai nutrisi dan peningkatan kecernaan (Kiers et al., 2000). Teknologi fermentasi biasanya memanfaatkan bakteri Aspergillus oryzae atau mikroba lainnya.

Hasil hasil penelitian menunjukkan bahwa kombinasi teknik pengolahan seperti pengolahan seperti perendaman, pemasakan, perkecambahan dan fermentasi akan memperoleh hasil yang lebih baik dibandingkan dengan metode pengolahan tunggal. Hasil penelitian Nunes et al. (2005) dan Liang et al. (2008) menunjukkan bahwa jangka waktu perendaman yang lama sebelum difermentasi atau perkecambahan akan mengakibatkan penurunan kadar asam fitat dan peningkatan bioavailabilitas mineral. Menurut penelitian Almashyuri et al. (1990), perebusan dan perendaman kedelai dapat menurunkan kandungan asam fitat sekitar 31,5\% sampai dengan 43\%. Penelitian Duhan et al (1999) pada kacang gude (Cajanus cajan) menunjukkan bahwa metode perendaman selama periode waktu yang berbeda bisa menurunkan asam fitat sebesar 6-22\% dibandingkan dengan kontrol. Hal tersebut menandakan bahwa waktu perendaman berpengaruh terhadap kandungan asam fitat dalam kacang gude. Hasil penelitian Mahesh et al. (2015) menunjukkan bahwa proses perendaman, perkecambahan dan fermentasi kacang tanah, biji bunga matahari, kedelai, kacang Gude (Pigeon pea) dan beras dapat menurunkan kadar asam fitat. Namun demikian, penurunan tersebut tidak disertai dengan peningkatan ketersediaan $\mathrm{Zn}$ dan Fe. Hal tersebut kemungkinan karena tingginya kandungan serat dalam bijibijian tersebut. Sedangkan menurut Abd El-Moneim et al. (2012), kombinasi teknik pengolahan seperti pengolahan seperti perendaman, pemasakan, perkecambahan dan fermentasi akan menurunkan faktor antinutrisi seperti fitat, fenol, tanin dan enzim inhibitor dengan melepaskan enzim eksogen dan endogen seperti fitase yang terbentuk selama pengolahan.

Kultivar tanaman rendah fitat asam jagung, beras, kedelai, gandum, dan barley juga telah dikembangkan dan diharapkan memiliki potensi untuk meningkatkan efisiensi fosfor dalam makanan hewan (Larson et al., 1998). Peningkatan ketersediaan fosfor dengan pemberian pakan kultivar barley rendah asam fitat terlihat pada unggas dan babi (Li et al., 2001; Veum et al., 2002). Menurut Khan et al. (2007) terdapat korelasi positif antara ketebalan kulit biji dengan kandungan asam fitat. Namun demikian, berat biji memiliki korelasi negatif dengan kandungan asam fitat. Dengan demikian, ketebalan 
kulit serta berat biji dapat digunakan sebagai penanda fisiologis untuk kandungan asam fitat.

Metode perendaman dan perkecambahan tampaknya menjadi metode yang paling mudah dan murah untuk dilakukan, terutama untuk peternak unggas dengan skala kecil. Namun demikian yang perlu menjadi perhatian adalah seberapa lama hasil perendaman dan perkecambahan dapat bertahan digunakan sebagai pakan ternak. Metode tersebut kemungkinan akan efektif jika digunakan dalam jumlah atau skala kecil sehingga dapat dimanfaatkan secara maksimal tanpa merubah nilai nutrisi yang ada. Metode penurunan kandungan asam fitat tersebut diatas tetap memiliki kelemahan kelemahan yang perlu diatasi untuk memperoleh metode baru yang mampu memperoleh hasil maksimal. Metode baru tersebut diharapkan mampu menurunkan kandungan fitat tetapi tidak menyebabkan penurunan nilai nutrisi yang lain yang terkandung di dalamya.

\section{FITASE}

Fitase adalah mio-inositol heksafosfat fosfohidrolase yang memiliki kemampuan menghidrolisis fitat.Fitase mengkatalisis pengambilan ortofosfat anorganik secara bertahap dari asam fitat melalui inositol-pentafosfat untuk menjadi monofosfat dan produk antara lainnya (Oluyinka, 2012).Fitase aktif asal mikroba banyak ditemukan pada spesies fungi dan aspergillus. Shieh dan Ware (1968), menyatakan bahwa hasil penyaringan pada isolat tanahterdapat lebih dari dua ribu (2000) mikroorganisme yang mampu menghasilkan fitase. Secara umum, fitase berasal dari empat sumber yaitu : fitase tanaman, fitase mikroba (jamur dan fitase bakteri), fitase yang dihasilkan oleh mukosa usus kecil dan usus yang terkait fitase mikroflora (Kumar et al., 2010).

Pada berbagai bahan makanan aktivitas fitase dapat menurunkan level asam fitat. Rye, gandum dan dedak gandum mengandung paling banyak fitase aktif dibandingkan semua jenis biji-bijian sereal (Harland and Harland, 1980; Ravindran et al., 1995). Sebaliknya jagung, sorgum, kedelai dan oilseeds memiliki aktivitas fitase endogen yang rendah. Dengan demikian, sebaiknya bahan pakan utama pada monogastrik berupa rye dan dedak gandum karena memiliki fitase dengan aktivitas yang tinggi. Namun demikian, hal tersebut masih memerlukan pertimbangan yang masak karena harga bahan pakan tersebut relatif mahal. Rendahnya aktivitas fitase endogen dalam biji tanaman sereal, legum, dan oilseed plant, dedak padi dan bungkil kedelai menyebabkan munculnya penggunaan fitase eksogen yang memanfaatkan mikroorganisme sebagai sumbernya.

Ternak monogastrik tidak menghasilkan fitase dalam jumlah yang cukup sehingga perlu penambahan secara rutin fitase eksogen ke dalam pakan sehingga dapat dimanfaatkan untuk memecah ikatan fitat-P (Kornegay, 2001). Beberapa dekade terakhir, penggunaan fitase asal mikroorganisme dalam diet unggas telah meningkat secara nyata, penambahan fitase asal mikroorganisme (Aspergillus niger,Peniophora lycii, dan Escherichia coli) yang telah mengalami rekayasa genetika (Genetically Modified Organisms) ke dalam pakan ternak semakin banyak dilakukan oleh pabrik pakan. Hal tersebut terutama bertujuan untuk meningkatkan produksi dan menanggapi kekhawatiran munculnya pencemaran lingkungan fosfor asal kotoran industri peternakan unggas 
maupun babi. Penggunaan fitase asal mikroorganisme tersebut juga mampu menekan biaya pakan dengan mengurangi komponen $\mathrm{P}$ yang mahal (Khan et al., 2013). Fitase telah banyak diisolasi dari berbagai mikroba seperti jamur, bakteri,dan protozoa.Seba gian besar enzim ini berasal dari kelompok asam histidin fosfatase atau dari alkalin fitase. Beberapa diantara enzim tersebut telah digunakan sebagai suplemen pakan ternak (Wysset al., 1999; Poliana and MacCabe, 2007).

Pakan ternak yang diberi tambahan fitase asal mikroorganisme tidak memerlukan penambahan fosfat ke dalam ransum. Dengan demikian ternak juga akan mengekskresikan fosfat dalam jumlah sedikit sehingga diharapkan akan menurunkan pencemaran lingkungan. Dampak menguntungkan yang lain adalah fitase asal mikroorganisme dalam ransum unggas memiliki dampak hidrolisis langsung pada asam fitat dan selanjutnya akan meningkatkan ketersediaan mineral, asam amino, dan energi (Selle and Ravindran, 2007). Ravindran et al. (2000) melaporkan bahwa penambahan fitase sebesar 750 FTU/kg menghasilkan kecernaan fosfor yang tinggi dibandingkan penambahan dibawah 500 FTU/kg ransum. Hasil penelitian tersebut juga didukung oleh Juanpere et al. (2004) yang menyatakan bahwa pada broiler umur 7 sampai 21 hari menunjukkan bahwa penambahan fitase asal mikroorganisme (500 FTU $\mathrm{Kg}^{-1}$ ) dalam pakan yang mengandung 2,7 $\mathrm{g} \mathrm{Kg}^{-1} \mathrm{P}$ akan meningkatkan berat badan 35g /ekor /hari dibandingkan dengan kontrol 34g /ekor/ hari. Nilai rasio konversi pakan (FCR) perlakuan adalah 1,4 dibandingkan dengan kontrol 1,5. Olukosi et al. (2007) menambahkan bahwa ada peningkatan pertumbuhan broiler yang diberi pakan defisiensi $\mathrm{P}$ dengan penambahan fitase. Penelitian
Shirley and Edwards (2003) juga menyatakan bahwa broiler dengan pemberian pakan campuran jagung dan kedelai yang kemudian ditambahkan fitase dari 0 FTU/kg sampai dengan 12.000 FTU/kg akan meningkatkan total degradasi fitat dalam saluran pencernaan dari 40,3\% menjadi 94,8\% .

Namun demikian, yang perlu diperhatikan adalah penambahan $\mathrm{Ca}$ dalam pakan broiler.Menurut Wise (1983) meningkatnya kandungan $\mathrm{Ca}$ dalam pakan dapat mengakibatkan terbentuknya kompleks Ca-fitat yang tidak terlarut.Hal tersebut kemungkinan disebabkan meningkatnya kandungan $\mathrm{P}$ untuk mengatur penurunan aktivitas fitase endogen mukosa, sedangkan fitase endogen mukosa memiliki potensi untuk menurunkan fitat pada unggas (Maenz dan Classen, 1998). Hasil penelitian Tamim et al. (2004) menunjukkan bahwa peningkatan kandungan $\mathrm{Ca}$ dalam pakan dari 2,0-7,0 g / kg akan mengakibatkan penurunan pembongkaran asam fitat oleh fitase endogen dalam ileum.

Hasil hasil penelitian menunjukkan bahwa penambahan fitase asal mikroorganisme dalam pakan babi mampu melepaskan ikatan fitat-P sehingga meningkatkan $\mathrm{P}$ yang dapat dicerna dan mengurangi ekskresi $\mathrm{P}$ dari babi (Cromwell et al., 1995; Almeida dan Stein, 2012; Kerr et al., 2010). Sejumlah penelitian menunjukkan bahwa penambahan fitase efektif dalam meningkatkan performa, retensi $\mathrm{P}$, peningkatan aktivitas plasma alkali fosfatase dan mineralisasi tulang melalui peningkatan hidrolisis fitat $\mathrm{P}$ pada babi (Coelho dan Kornegay, 1996). Hal tersebut menunjukkan bahwa penambahan fitase ke dalam campuran jagung dan kedelai pada pakan babi muda akan meningkatkan retensi P sekitar 10 sampai 20\% (Jongbloed dan Kemme, 1990; Wenk et al., 1993). Pemberian pakan dengan 
kandungan $\mathrm{Ca}$ yang tinggi pada babi akan menimbulkan efek penurunan kinerja fitase asal mikroorganisme dan mempengaruhi kecernaan $\mathrm{P}$ (Lei et al., 1994; Lantzsch et al., 1995). Efek penurunan kinerja fitase akibat penambahan $\mathrm{Ca}$ dalam pakan tersebut kemungkinan dapat disebabkan melalui beberapa mekanisme. Mekanisme tersebut kemungkinan adalah terbentuknya komplkes Ca-fitat yang tidak terlarut dalam usus halus atau (Selleet al., 2009). Kemungkinan lain menurutSandberg et al. (1993) karena konsentrasi $\mathrm{Ca}$ yang tinggi akan meningkatkan $\mathrm{pH}$ dalam usus sehingga mengakibatkan turunnya aktivitas fitase.

Secara umum penambahan fitase memberikan manfaat yang besar dibidang industri peternakan terutama ternak monogastrik seperti babi dan unggas. Namun karena fitase berasal dari beberapa sumber seperti tanaman, mikroba (jamur dan bakteri) dan fitase terkait mikroflora maka perlu diperhatikan pemilihan fitase dalam pakan yang paling efisien dalam peningkatan produksi ternak. Seperti yang dikatakan oleh Shimizu, (1992) bahwa ada kendala dalam menentukan asal fitase untuk menentukan pilihan terbaik dalam kemampuannya membebaskan ikatan fosfor fitat sehingga meningkatkan kecernaan fosfor dan penyerapan mikro mineral lainnya pada sumber pakan. Hal tersebut kemungkinan disebabkan karena perbedaan kondisi percobaan dan kemurnian dari preparasi enzim.

\section{KESIMPULAN}

Meskipun fitat merupakan antinutrisi yang dapat mengganggu produktivitas ternak namun demikian melalui berbagai pemrosesan kandungannya dapat diturunkan.Metode perendaman dan perkecambahan tampaknya menjadi metode yang paling mudah dan murah untuk dilakukan, terutama untuk peternak unggas dengan skala kecil.Pemrosesan bahan pakan yang mengandung fitat terutama lebih ditujukan pada pakan ternak non ruminansia. Selain pemrosesan bahan pakan, penggunaan fitase merupakan pilihan yang tepat untuk industri peternakan terutama ternak monogastrik seperti babi dan unggas.

\section{DAFTAR PUSTAKA}

Abd El-Moneim, M. R. A., El-Beltagi, H. S. Abd El-Salam, S. M. Omran,A. A.2012.Effect of Soaking, Cooking, Germination and Fermentation Processing on Proximate Analysis and Mineral Content of Three White Sorghum Varieties (Sorghum bicolor L. Moench).Not Bot Horti Agrobio, $40(2)$, 92-

98: http://dx.doi.org/10.15835/ nbha4027930

Abdel-Gawad, A.S. 1993.Effects of domestic processing on oligosaccharide content of some dry legume seeds.Food Chem, 46 (1), $25-$ 31./doi/pdf/10.1094/CC-830428

Akande, K. E., Doma, U. D.,Agu, H. O. and Adamu,H. M. 2010. Major antinutrients found in plant protein sources: their effect on nutrition. Pakistan J. Nutr, 9(8), 827-832. doi: 10.3923/pjn.2010.827.832

Akindahunsi, A. A. 2004. Physicochemical studies on African oil bean (Pentaclethra macrophylla Benth.) seed. Journal of Food Agriculture and Environment, 2, 4-17. Accesion: 004269993

Almasyhuri, A., Yuniati, H.D., and Slamet,S.1990. Kandungan Asam Fitat Dan Tanin Dalam 
Kacang-Kacangan Yang Dibuat Tempe. PGM, 13, 65-72.

Almeida, F. N., and Stein,H. H. 2012. Effects of graded levels of microbial phytase on the standardized total tract digestibility of phosphorus in corn and corn coproducts fed to pigs. J. Anim. Sci,90,1262-1269. doi:10.2527/jas.2011-4144

Angel, R., Tamim, N. M.,Applegate, T. J.,Dhandu, A. S.,and Ellestad, L. E. 2002. Phytic acid chemistry: influence on phytinphosphorus availability and phytase efficacy. The Journal of Applied Poultry Research, 11 , 471480.doi:https://doi.org/10.1093 /japr/11.4.471

Anggorodi, R. 1995. Ilmu Makanan Ternak Unggas Kemajuan Mutakhir Fakultas Peternakan IPB, Bogor.

Baldwin, P.M. 2001. Starch granuleassociated proteins and polypeptides: a review. Starch/Starke,53,475503.doi.org/10.1002/1521379X(200110)53:10<475::AID -STAR475>3.0.CO;2-E

Bebot-Brigand, A., Dange, C., Fauconnier, N.,and Gérard,C. 1999. 31P NMR, potentiometric and spectrophotometric studies of phytic acid ionization and complexation towards $\mathrm{Co}^{+}$, $\mathrm{Ni} 2^{+}, \mathrm{Cu} 2^{+}, \mathrm{Zn} 2^{+}$, and $\mathrm{Cd} 2^{+} . J$ Inorg Biochem,75, 71-78.doi: 10.1016/S0162-

0134(99)00041-0

Bilyeu, K.D., Zeng, P.,Coello, P.,Zhang,

Z.J.,KrishnanBailey,H.B., Beuselinck, P.R., and Polacco,J.C. 2008. Quantitative conversion of phytate to inorganic phosphorus in soybean seeds ex- pressing a bacterial phytase. Plant Physiol, 146, 468-477. doi: http://dx.doi.org/10.1104/ pp.107.113480

Bohn, L., Meyer, A.S. and Rasmussen. S.K. 2008.Phytate : Impact on environment and human nutrition. A challenge for molecular breeding.J. Zhejiang Univ. Sci.B, 9, 165-191. doi: 10.1631/jzus.B0710640

Cheryan, M. 1980. Phytic acid interactions in food systems.CRC Crit Rev Food Sci,13, 297335.doi:10.1080/10408398009 527293

Coelho, M. B., and Kornegay,E. T. 1996. Kornegay, E. T (Ed.) :Phytase in Animal Nutrition and Waste Management (M. B.), BASF Corporation, Mount Olive, NJ.

Conrad, B., Savchenko, R.S.,Breves, R., and Hofeweister,J.1996. A T7 promoterspecific, inducible protein expression system for.Bacillus subtilis.Mol Gen Genet, 5, 250(2),230-236.doi: 10.1007/BF02174183

Cromwell, G. L., Coffey, R. D.,Parker, G. R.,Monegue, H. J., and Randolph,J. H.1995. Efficacy of a recombinant-derived phytase in improving the bioavailability of phosphorus in corn-soybean meal diets for pigs. J. Anim. Sci, 73, 20002008.doi: 10.2527/1995.7372000x

Deshpande, S. S., and Damodaran,S.1989. Effect of phytate on solubility, activity and conformation of trypsin and chymotrypsin.Journal of Food Science, 54, 695699.doi: $10.1111 / \mathrm{j} .1365$ 2621.1989.tb04684.x 
Dhankher, N., and Chauhan,B. M.1987.Effect of Temperature and Fermentation Time on Phytic Acid and Polyphenol Content of RabadiA Fermented Pearl Millet Food. Journal of Food Science,52(3), 828829.DOI: $10.1111 / \mathrm{j} .13652621$. 1987.tb06739.x

Duhan, A., Khetarpaul, N., and Bishnoi,S.1999. Effect Of Various Domestic Processing And Cooking Methods On Phytic Acid And HciExtractability Of Calcium, Phosphorus And Iron Of Pigeon pea.Nutrition And Health, 13, 161-169. doi/pdf/10.1177/026010609901 300304

Egounlety, M., and Arowh,O. C. 2003.Effect of soaking, dehulling, cooking and fermentation with Rhizopus oligosporus on the oligosaccharides, trypsin inhibitor, phytic acid and tannins of soybean (Glycine max Merr.), cowpea (Vigna unguiculata $L$. Walp) and groundbean (Macrotyloma geocarpa Harms).Journal of Food Engineering, 56,249 254.doi: 10.1016/S02608774(02)00262-5

El-Adawy, T. A. 2002.Nutritional composition and antinutritional factors of chickpeas (Cicerarietinum L.) undergoing different cooking methods and germination.Plant Foods for Human Nutrition, $\quad 57, \quad 83-$ 97.doi:10.1023/A:1013189620 528

Glencross, B., and Carter.,C. 2007. Field peas and aquafeeds.Proceedings of the Fourth Workshop Harvesting the benefits of grain in aquaculture feeds. 13 February 2007. 42-49, Publ. Department of Fisheries Fremantle, ISSN 1447-2068, Western Australia.

Grafs, E., Empson, K.L.,and Eaton, J.W.1987. Phytic acid. A natural antioxidant.The Journal of Biological Chemistry, 262, 11647-11650.

Greiner, R., and Konietzny,U. 2011. Phytase: biochemistry, enzymology and characteristics relevant to animal feed use. In: M.R. Bedford and G.G. Partridge (eds.). Enzymes in Farm Animal Nutrition 2nd Ed. USA: CABI Pub.,96-128.

Gupta, R. K., Gangoliya, S. S., and Singh,N. K. 2013.Reduction of phytic acid and enhancement of bioavailable micronutrients in food grains.J. Food Sci. Technol, 52(2), 676-684DOI 10.1007/s13197-013-0978.

Harland, B. F., and Harland,J. 1980. Fermentative Reduction of Phytate in Rye, White, and Whole Wheat Breads.Cereal Chem, 57,226 - 229.

Harland, B. F., and Prosky,L.1979. Development of dietary fiber values for foods. Cereal Foods World, 24:387-394.

Hernaman, I., Toharmat, T., Manalu, W., dan Pudjiono.P.I.2007.Studi pembuatan Zn-fitat dan degradasinya di dalam cairan rumen secara in vitro.Jurnal Pengembangan Peternakan Tropis, 32 (3),139145

Humer, E., Schwarz, C., and Schedle,K.2015. Review Article Phytate in pig and poultry nutrition. Journal of Animal Physiology and Animal Nutri- 
tion, 99 ,

$605-$

625.doi: 10.1111/jpn.12258.

Jarrett, J.P., Wilson, J.W.,Ray, P.P.,and Knowlton,K.F. 2014.The effects of forage particle length and exogenous phytase inclusion on phosphorus digestion and absorption in lactating cows.Journal of Dairy Science, 97, 411-418.doi: 10.3168/jds.2013-712

Jongbloed, A. W., Mroz, Z., and Kemme,P. A. 1992. The effect of supplementary Aspergillus nigerphytase in diets for pigs on concentration and apparent digestibility of dry matter, total phosphorus, and phytic acid in different sections of the alimentary tract. J. Anim. Sci, $70(4)$, $1159-$ 1168.doi:10.2527/1992.704115 $9 \mathrm{x}$

Juanpere, J., Perez-Vendrell, A.M., and Brufau,J. 2004. Effect of microbial phytase on broilers fed barley-based diets in the presence or not of endogenous phytase. Animal Feed Science and Technology,115,(3-4) 265279.DOI: http://dx.doi.org/10.1 016/j.anifeedsci.2004.02.002

Kasim, A.B., and Edwards Jr., H. 1998. The analysis for inositol phosphate forms in feed ingredients. J. of Food Sci. and Agric., $76(1), 1-$

9.DOI:10.1002/(SICI)10970010(199801)76:1<1

Kaushik, G., Satya, S.,and Naik, S.N. 2010. Effect of domestic processing techniques on the nutritional quality of the soybean.Mediterranean Journal of Nutrition and Metabolism, 3(1), 39-46. DOI: 10.1007/s12349-009-0079-7
Kerovuo, J, Lappalainen, I., and Reinikainen,T. 2000. The metal dependence of Bacillus subtilis phytase.Biochem.Biophys.Res. Comm., 268:365-369. DOI:10.1006/bbrc.2000.2131

Kerr, B. J., Weber, T. E.,Miller, P. S, and Southern,L. L. 2010. Effect of phytase on apparent total tract digestibility of phosphorus in corn-soybean meal diets fed to finishing pigs. $J$. Anim. Sci., 88(1), 238-247. DOI:10.2527/jas.2009-2146

Khan, A.J., Ali, A.,Farooq-i-A., and Zeb, A. 2007. Identification and isolation of low phytic acid wheat (Triticum aestivum L.) inbred lines / mutants. Pak. J. Bot., 39(6), 20512058.pjbot/PDFs/39(6)/PJB39( 6)2051

Khan, S.A., Chaudhry,H.R., Butt, Y.S.,Jameel,T.,and Ahmad,F. 2013.The Effect of Phytase Enzyme on the Performance of Broiler Flock (AReview).Poultry Science Journal. 1 (2), 117-125.doi: 10.22069/PSJ.2016.10564.117 4.

Kiers, J.L., Van Laeken, A.E.,Rombouts, F.M., and Nout, M.J.2000. In vitro digestibility of bacillus fermented soya bean. International Journal of Food Microbiology,60(2-3),163-169. doi.org/10.1016/S01681605(00 )00308-1

Kornegay, E. T. 2001. Digestion of phosphorus and other nutrients: the role of phytases and factors influencing their activity.In: Enzymes in farm animal nutrition. Pp 237-271. CABI Publishing Wallingford. 
Kumar, V., Sinha, A. K., Makkar, H. P. S., and Becker,K.2010. Dietary roles of phytate and phytase in human nutrition: A review. Food Chemistry, 120(4), 945959.doi:10.1016/j.foodchem.20 09.11 .052

Laboure, A. M., Gagnon, J., and Lescure,A. M. 1993. Purification andcharacterization of a phytase (myo-inositolhexakispho phatephosphohydrolase) accumulated in maize (Zea mays) seedlings during germination. Biochemical Journal, 295(2), 413-419.doi: 10.1042/bj2950413.

Lantzsch, H. J. S., and Drochner,W. 1995.The effect of dietary calcium on the efficacy of microbial phytase in rations for growing pigs.J. Anim. Physiol. Anim. Nutr., 73(1),19-26. doi: $10.1111 / \mathrm{j} .1439$ 0396.1995.tb00399.x

Larson, S. R., Young, K. A.,Cook, A., Blake, T. K., and Raboy,V.1998.Linkage mapping of two mutations that reduce phytic acid content of barley grain.Theor. Appl. Genet., 97(1),141146.doi:10.1007/s0012200508 78

Lei, X. G., Ku, P. K.,Miller, E. R., Yokoyama, M. T., and Ullrey,D. E. 1994. Calcium level affects the efficacy of supplemental microbial phytase in corn-soybean meal diets of weanling pigs. J. Anim. Sci.,72(1),139143.doi:10.2527/1994.721139x

Li, Y. C., Ledoux, D. R., and Veum,T. L. 2001.Bioavailability of phosphorus in low phytic acid barley.J. Appl. Poultry Res., 10(1),86- 91.doi:https://doi.org/10.1093/ja $\mathrm{pr} / 10.1 .86$

Liang, J., Han, B.Z., Nout, M.J.R., and Hamer,R.J. 2008. Effects of soaking, germination and fermentation on phytic acid, total and in vitro soluble zinc in brown rice. Food Chem. Vol, 110(4), 841848.doi: 10.1016/j.foodchem.2 008.02 .064

Lim, S.J., KimS.S., Pham, M.A.,Song, J.W.,Cha, J.H.,Kim, J.D.,Kim, J.U.,and Lee,K.J. 2010. Effects of fermented cottonseed and soybean meal with phytase supplementation on gossypol degradation, phosphorus availability, and growth performance of olive flounder (Paralichthys olivaceus). Fisheries and Aquatic

Sciences, 13(4),284-293.doi : 10.5657/fas.2010.13.4.284

Lolas, G. M., Palamidis, N., and Markakis,P. 1976. The phytic acid total phosphorus relationships in barley, oats, soybeans and wheat.Cereal Chem., 53, 867871.

Maenz, D.D., and Classen,H.L. 1998. Phytase activity in the small intestinal brush border membrane of the chicken.Poultry Science,77(4), 557563.doi:https://doi.org/10.1093 $/ \mathrm{ps} / 77.4 .557$

Mahajan, S., and Chauhan, B.1987. Phytic acid and extractable phosphorus of pearl millet flour as affected by natural lactic acid fermentation.J. Sci. Food Agric., 41(4), 381386.

doi: 10.1002/jsfa.274041040

Mahesh, S., Pavithra, G.J., Parvathi, M.S., Rajashekara, R., and Shankar,A. G. 2015.Effect of 
processing on phytic acid content and nutrient availability in food grains. Int. J. Agric. Sci., 5(5), 771-777.

Mahmod, M. H., Abu-Salem, F. M., ElKalyoubi, M. H., and Gibriel, A. Y. 2007. Effect Of Legume Processing And Fermentation Treatments On Their Phytic Ac-

id.iufost.org.br/sites/iufost.org. br/files/anais/01073.pdf

Morris, E.R. 1986. Phytate and dietary mineral bioavailability. In: Phytic acid chemistry and applications. E. Graf, Ed. Pilatus Press, Minneapolis, USA

Morse, D., Head,H. H., and Wilcox,C. J. 1992. Disappearance of phosphorus in phytate from concentrates in vitro and from rations fed to lactating dairy cows. J. Dairy Sci., 75(7),1979-1986.doi: $10.3168 /$ jds.S00220302(92)77957-0

National Research Council. 2012. Nutrient requirements of swine. 11 th Ed. National Academy Press, Washington, DC.

Nunes, A.C.S., Viana, G.R., Cuneo,F., Amaya-Farfán, J., Capdeville, G.D., Rech, E.L., and Aragão,F.J.L. 2005. RNAi- mediated silencing of the myoinositol-1-phosphate syn- thase gene (GmMIPS1) in transgenic soybean inhibited seed development and reduced phytate content. Planta, 224(1),125132.doi:10.1007/s00425-0050201-0

O'Dell, B.L., de Boland, A.R., and Koirtyohann,S.T. 1972. Distribution of phytate and nutritionally important elements among the morphological components of cereal grains.J. Agric. Food Chem., 20(3), 718723.doi: 10.1021/jf60181a021

Ologhobo, D. A., and Fetuga, B. L. 1982. Polyphenols, phytic acid and other phosphorus compounds of lima bean (Phaseolus lunntis). Nutrition Reports International, 26, 605-611.

Olukosi, O. A., Cowieson, A. J., and Adeola, O. 2007. Age-related influence of a cocktail of xylanase, amylase, and protease or phytase individually or in combination in broilers. Poultry Science, 86(1), 7786. doi:https://doi.org/10.1093/ ps/86.1.77

Olukosi,O.A. 2012. Review Article: Biochemistry of phytate and phytases: Applications in monogastric nutrition.Biokemistri, 24(2) 58-63

Osman, A.M. 2007. Effect of different processing methods on nutrient composition, antinutrient factors and invitro protein digestibility on Dolichos lablab bean (Lablab purpureus $L$ sweet).Pak. J. Nutr.,6(4), 299303.

Pallauf, J., and Rimbach G.1996. Nutritional Significance of Phytic Acid and Phytase. Arch.Anim. Nutr.,50(4),301-319. dx.doi.org/10.1080/174503997 09386141

Panhwar F. 2005. Anti-Nutritional Factors in Oil Seeds as Aflatoxin in Groundnut.Digitalverlag GmbH, Germany, Edn Chemlin.

Park, W.Y., Matsui,T., and Yano,H. 2002.Post-ruminal phytate degradation in sheep.Animal Feed Science and Technolo- 
gy, 101(1-4),

55-60.

doi: http://dx.doi.org/10.1016/S

0377-8401(02)00181-5

Piliang,W. G., Sastradipradja, D., dan Manula,W. 1982. Pengaruh penambahan berbagai tingkat kadar $\mathrm{Zn}$ dalam ransum yang mengandung dedak padi terhadap penampilan serta metabolism $\mathrm{Zn}$ pada ayam-ayam petelur. Laporan Penelitian. Direktorat Pembinaan penelitian dan pengabdian pada masyarakat.Direktorat Jendral Pendidikan Tinggi Departemen Pendidikan dan Kebudayaan.

Poliana, J., and MacCabe,A.P. 2007. Industrial Enzymes; Structure, Function, and Applications.Dordrecht: Springer: 505-508. ISBN 978-1-40205376-4

Raboy, V., and Dickinson,D. B.1993.Phytic Acid Levels in Seeds of Glycine max and $G$. soja as Influencedby Phosphorus Status.Crop Science,33(6), 1300-1305.doi:

10.2135/cropsci1993.0011183 X003300060036x

Ravindran, V., Cabahug,S., Ravindran, G.,Selle, P.H., and Bryden, W.L. 2000. Response of broiler chickens to microbial phytase supplementation as influenced by dietary phytic acid and nonphytate phosphorus levels. II. Effects on apparent metabolisable energy, nutrient digestibility and nutrient retention. British PoultryScience,41(2),193200.doi:10.1080/00071660050 022263

Ravindran, V., Bryden, W.L., and Kornegay, E.T. 1995. Phytases: occurrence, bioavailability and implications in poultry nutri- tion. Poultry Avian Biological Review, 6(2) 125-143.

Reddy, N. R., Pierson, M. D.,Sathe, S. K., and Salunkhe,D. K. 1989.Occurrence, distribution, content and dietary intake of phytate. In: N. R. Reddy, M. D. Pierson, S. K. Sathe, D. K. Salunkhe (eds) Phytates in Cereals and Legumes. CRC Press, Boca Raton, FL, pp. 47.

Reddy, N. R., Sathe, S. K., and Salunkhe,D. K. 1982.Phytates in legumes and cereals.Adv. Food Res, 28,1-92.PMID:6299067

Reinhold, J. G. 1975. Phytate destruction by yeast fermentation in whole wheat meals.Study of high-extraction rate meals.Journal of the American Dietetic Association, 66 (1), 32-41.

Rickard, S.E., and Thompson,L.U. 1997. Interactions and biological effects of phytic acid. In: Antinutrients and phytochemicals in food. Shaidi, F. (ed). American Chemical Society, Washington, DC. pp: 294-312.

Sandberg, A. S., Larsen, T., and Sandstrom,B. 1993. High dietary calcium level decreases colonic phytate degradation in pigs fed a rapeseed diet. J. Nutr., 123(3), 559-566.

Sangronis, E., Rodriguez, M., Cava, R., and Torres,A.2006. Protein quality of germinated PhaseolusVulgaris.European Food Research and Technology, 222(1), 144148.doi:10.1007/s00217-0050137-4

Schlemmer, U., Frolich, W., Prieto, R. M.,and Grases,F.2009. Phytate in foods and significance for humans: food sources, intake, processing, bioavailability, 
protective role and analysis. Molecular Nutrition and Food Research, 53(52), S330 S375. doi:10.1002/mnfr.20090 0099

Schlemmer, U., Jany, K. D., Berk, A., Schulz, E., and Rechkemmer, G.2001. Degradation of phytate in the gut of pigs - pathway of gastrointestinal inositol phosphatehydrolysisand enzymes involved. Archives of Animal $\mathrm{Nu}$ trition, 55(4), 255-280. dx.doi.org/10.1080/1745039010 9386197

Selle, P. H., Cowieson, A. J., and Ravindran,V. 2009. Consequences of calcium interactions with phytate and phytase for poultry and pigs.Livestock Science, 124(1-3), 126-141.

DOI: http://dx.doi.org/10.1016/j. livsci.2009.01.006

Selle, P. H., V. Ravindran, R. A. Caldwell, and W. L. Bryden. 2000. Phytate and phytase: Consequences for protein utilization. Nutr. Res. Rev.,13(2), 255-278. doi:10.1079/0954422001087290 98

Selle, P.H., and Ravindran,V.2007.Microbial phytase in poultry nutrition.Animal Feed Science and Technology, 135(12), $1-41$. DOI: http://dx.doi.org/10.1016/j. anifeedsci.2006.06.010

Selle, P.H., and Ravindran,V.2008. Phytate-degrading enzymes in pig nutrition. Livestock Science, 113(2-3), 99-122.doi: 10.1016/j.livsci.2007.05.014

Shimelis, E. A., and Rakshit, S. K. 2007.Effect of processing on antinutrients and in vitro protein digestibility of kidney bean (Phaseolus vulgaris L.) varieties grown in East Afri-
ca.Food Chemistry, 103(1), 161-172.doi:

10.1016/j.foodchem.2006.08.0 05

Shimizu, M. 1992. Purification and Characterization of Phytase from Bacillus suhtilis(natto) $\mathrm{N}$ 77.Biosci.Biotech. Biochem., 56(8), 1260-1269. doi.org/10.1271/bbb.56.1266

Shirley, R. B., and Edwards,H. M. 2003. Graded levels of phytase past industry standards improves broiler performance. Poultry Science,82(4), 671680.doi:https://doi.org/10.1093 $/ \mathrm{ps} / 82.4 .671$

Siddhuraju, P., and Becker,K. 2001. Preliminary nutritional evaluation of Mucuna seed meal (Mucuna pruriens var utilis) in common carp (Cyprinus carpio $L)$ : An assessment by growth performance and feed utilization. Aquaculture, 196(12), 105123.doi.org/10.1016/S00448486(00)00577-9.

Singh, U., Singh, B., and. Smith,O. D. 1991. Effect of varieties and processing methods on phytic acid and protein digestibility of groundnut (Arachis hypogaea).Journal of Food Science and Technology,28(6),345-347.

Soares Jr., J. H. 1995. Phosphorus bioavailability. In: Bioavailability of Nutrients for Animals: Amino Acids, Mineral and Vitamin. B. A Clarence, D. H. Baker, A. J. Lewis (eds.). Academic Press, California.

Sokrab, A.M., Mohamed, A. I.A., and Babiker,E.E. 2012. Effect of germination on antinutritional factors, total, and extractable minerals of high and low phytate corn (Zea mays L.) geno- 
types.Journal of the Saudi Socie-

ty of Agricultural

Sciences, 11(2), 123-128.

doi.org/10.1016/j.jssas.2012.02.

002

Steiner, $\quad$ T., Mosenthin,

R.,Zimmermann, B., Grein-

er,R., and Roth,S. 2007. Distri-

bution of phytase activity, total

phosphorus and phytate phos-

phorus in legume seeds, cereals

and cereal by-products as in-

fluenced by harvest year and

cultivar. Anim Feed Sci Tech-

nol.,133(3-4), 320-334.doi:

10.1016/j.anifeedsci.2006.04.0

07

Tamim, N.M., Angel, R., and Christman, M. 2004. Influence of dietary calcium and phytase on phytate phosphorus hydrolysis in broiler chickens. Poultry Science,83(8),1358-1367. DOI: $10.1093 / \mathrm{ps} / 83.8 .1358$

Tyagi, P. K., and Verma,S. V. S. 1998. Phytate phosphorus content of some common poultry feed stuffs. Indian Journal of Poultry Science, 33(1), 86-88.

Urbano, G., Lopez-Jurado, M., Aranda, P., Vidal-Valverde, C., Tenorio, E., and Porres,J. 2000. The role of phytic acid in legumes: antinutrient or beneficial function.Journal of Physiology and Biochemistry, 56(3), 283-294. DOI: 10.1007/BF03179796

Veum, T. L., Ledoux, D. R., Bollinger, D. W.,Raboy,V., and Cook,A. 2002. Low-phytic acid barley improves calcium and phosphorus utilization and growth performance in growing pigs. J. Anim. Sci.,80(10),26632670.doi:10.2527/2002.801026 $63 \mathrm{x}$

Vidal-Valverde, C., Frias, J.,Sotomayor, C., and Diaz-Pollan, C.,
Fernandez, M., and Urbano, G. 1998. Nutrients and anti nutritional factors in faba beans as affected by processing. Zeitschrift für LebensmittelUntersuchung-undForschung,207(2), 140145.doi:10.1007/s0021700503 08

Weaver, C.M., and Kannan,S. 2002. Phytate and mineral bioavailability. In: Reddy NR, Sathe SK (eds). Food Phytates. CRC Press: Boca Raton, FL.

Wenk, C., Weiss, E.,Bee, G., and Messikommer, R. 1993. Interactions between a phytase and a carbohydrase in a pig diet.Enzymes in Anim. Nutr. Proc. 1st Symp-Kartause Ittingen, Switzerland : 160-164.

Wise, A.1983. Dietary factors determining the biological activity of phytates.Nutrition Abstracts and Reviews inClinical Nutrition, 53, 791-806.

Woyengo, T. A., A. J. Cowieson, O. Adeola, and C. M. Nyachoti. 2009. Ileal digestibility and endogenous flow of minerals and amino acids: responses to dietary phytic acid in piglets. $B r$. J. Nutr, 102(3), 428-433. DOI: 10.1017/S0007114508184719

Woyengo, T. A., and Nyachoti,C. M. 2013. Review: Anti-nutritional effects of phytic acid in dietsfor pigs and poultry current knowledge and directions for future research. Can. J. Anim. Sci., $\quad$ 93(1),921.doi: http://dx.doi.org/10.113 9/CJAS2012-017

Wyss, M., Brugger, R., Kronenberger, A.,Rémy, R., Fimbel, R.,Oesterhelt, G., Lehmann, M.,and van Loon,A.P.G.M. 1999. Biochemical characteri- 


\section{J. Ilmu-Ilmu Peternakan 26 (3): 59 - 78}

zation of fungal phytases (myo-inositol hexakisphosphate phosphohydrolases):

Catalytic properties. Appl. En- viron. Microbiol, 65(2),367373.PMCID: PMC91034 